University for Business and Technology in Kosovo

UBT Knowledge Center

Nov 1st, 2:30 PM - 2:40 PM

\title{
The New Public Management In Transition Countries- Public Sector Decentralization And Local Governance Reform In Kosovo
}

Ibrahim Krasniqi

University for Business and Technology, ibrakrasniqi@gmail.com

Follow this and additional works at: https://knowledgecenter.ubt-uni.net/conference

Part of the Business Commons

\section{Recommended Citation}

Krasniqi, Ibrahim, "The New Public Management In Transition Countries- Public Sector Decentralization And Local Governance Reform In Kosovo" (2013). UBT International Conference. 28.

https://knowledgecenter.ubt-uni.net/conference/2013/all-events/28

This Event is brought to you for free and open access by the Publication and Journals at UBT Knowledge Center. It has been accepted for inclusion in UBT International Conference by an authorized administrator of UBT Knowledge Center. For more information, please contact knowledge.center@ubt-uni.net. 


\title{
The New Public Management In Transition Countries- Public Sector Decentralization And Local Governance Reform In Kosovo
}

\author{
Ibrahim Krasniqi \\ University for Business and Technology, Prishtina, Republic of Kosovo \\ Ibrahim.Krasniqi@ubt-uni.net; ibrakrasniqi@gmail.com
}

\begin{abstract}
Public administration management in most developing countries is changing rapidly through reform processes with respect to public service delivery and the stimulation of economic growth. That change, in general is affected by the need for policy reform, has resulted in different structural public management reforms known as decentralization and 'the new public management', reflecting a movement away from the old values and norms of public administration management. This paper discusses the issue of local government reform processes in Kosovo in parallel with the new public management processes in the country. Local government reform has been and is a priority of the institutions of the Republic of Kosovo, and as such, it has gone through various stages of its evolution. In other words, special emphasis should be put also on the achievements, progress, challenges and difficulties of local government reformprocesses. As such, this paper reflects the ontological aspect of the new public management approach in local government reform in the Republic of Kosovo, starting from the development stages of this extensive process up to the current situation, including falls and downs of this process. Therefore, this paper reflects empirically (through research) the current status of local government in Kosovo, as well as the difficulties faced by the local government. As a result of the elaboration of this paper, we have come to the conclusion that local government has made a significant progress since the end of the war. However, much remains to be done in this regard, especially in terms of: transparency, accountability, citizen participation in decision-making, and many other processes, which further strengthen local democracy in the country.
\end{abstract}

Keywords: New public management, Kosovo, Local government, Decentralization, Reform,

\section{Introduction}

In Kosovo, as in the rest of Europe, the study of Public Administration has shown growing interest both in local government studies and in the modernization of public organizations. Often the provision of services has been delegated to individual municipalities increasing the need for general discussion about appropriate approaches and management tools. Various modernization ideas and activities around the world show that there is not any single model for efficient and effective public management. Country specific characteristics and traditions are central in the planning and implementation of public administration reforms. Countries with different development levels also have different goals of their reforms. For established democracies flexibility has been the keyword behind public administration reforms. Transitional countries on the other hand have too much flexibility due to general political and economic instability. They try to establish their traditions, principles and mindset of people in accordance with the new economic, social and political reality. Starting from the end of the 1980s, discussion about appropriate management practices and modernization initiatives has often been followed and enhanced by pro and con arguments of the New Public Management (NPM) approach. This approach is mostly referring to the market-oriented principles and private sector practices that are meant to be transferred to and applied by the public sector. The focus of this paper is on the current management practices in the Kosovo local government. The central aim is to analyze some of the main NPM type management ideas which Kosovo localgovernments have been experimenting with since the beginning of the 1990s. Although certain aspects of national and European levels are looked at and 
analyzed together with the characteristics of the transitional countries in Central and Eastern Europe (CEE), the main analysis concentrates on Kosovo local level. Only if the developments on the organizational level in Kosovo local governments are combined with the developments in the broader context, an adequate picture of an analysis could be expected.

\section{Development of Kosovo local government}

After the deployment of UNMIK international administration in Kosovo and after the establishment of domestic democratic institutions in central and local level, which was an important step towards the establishment and functioning of Kosovo bodies and institutions, a progressive transfer of responsibilities from international authorities to domestic authorities began. Further, the process of transfer of competencies from central level bodies to local level bodies took place, as well as the establishment of new municipalities. The process of establishment of new municipalities was preceded by the Framework Document on Local Government Reform of 2004, and SRSG's decision of 2005 on the establishment of Pilot Municipal Units.After the declaration of independence of the Republic of Kosovo and adoption of basic legislation on Local Self-Government as foreseen in CSP, the Ministry of Local Government Administration drafted and implemented the Action Plan on Decentralization since 2008.The Inter-Ministerial Group on Decentralization was established to supervise the implementation of decentralization. Until the declaration of Kosovo's independence, the legal setup, organization and functioning of the municipalities in Kosovo as basic units of local self-government were regulated through UNMIK regulations. After the declaration of independence, the MLGA sponsored the three basic laws on local self-government, which entered into force after the declaration of independence of the Republic of Kosovo: the Law on Local Self-Government No. 03/L-040; Law on Local Government Finance No. 03/L-049; and Law on Administrative Boundaries No. 03/L-041.

The local self- government in Kosovo protects and promotes internationally recognized human rights standards, with special consideration for the needs of non-majority communities and their members in Kosovo. Throughout the ongoing period of state building, a special attention is being paid to localselfgovernment in Kosovo, by ensuring through the law a municipal self-government, initially with limited competencies. While, as regards to essential changes in municipal bodies and their election, there were continuous changes since the organization of first local government elections held on 28 October 2000. In the process of decentralization, a special attention was paid to the establishment of new municipalities, transfer and delegation of competencies for central to local level. Initially, three pilot municipal units were established.

Later they became municipalities with equal prerogative as the rest of municipalities. Then, there is a second phase of the process of decentralization, which resulted in the establishment of $4+1$ new municipalities. The municipality of Mitrovica North is still in the process of establishment and this is one of challenges for the future. The Ministry of Local Government Administration has also, in coordination with their institutions, transferred all own competencies foreseen in the Law on Local SelfGovernment No. 03/L-040, from the central level to the local level, including both delegated and enhanced competencies according to the applicable legis lation, even that there needs continuously to be improvements in coordination. The strategic goal of the Government of Kosovo was creation of sustainable and effective systemoflocal self-government throughout the territory of Kosovo that would enable good living conditions for all of its citizens, which could be achieved through capacity building and human resources, financing of projects in infrastructure, as well as in coordination with foreign and domestic donors. Despite significant progress in terms of implementation of the process of decentralization, challenges remain. In order to advance this process and local self-government in Kosovo further, the MLGA is in the phase of finalization of the Strategy on Local Self-Government 2013 - 2016. This strategy will reflect upon, and include lessons learnt until now in order for the reform to advance further. 


\section{Centralization versus Decentralization in Public Administration Management}

After so much time of centralism, state reform has emerged as a necessity and has become, in relatively short time, a field of scientific preoccupations for researchers. Thus, a fair position in connection with this subject matter is possible by investigating various materials, articles, studies published in the field. This allows us to identify the main views, ideas and judgments issued with respect to the issue under discussion. About the issue of decentralization a lot has been said and a lot has been written, but ... from theory to reality ... is a long way to go if not impossible, especially in the current economic and political context. Notable and worthy of note is the mention made by Elinor Os trom in an interview with Foreign Policy Magazine in October 2010. When asked "Is decentralization a solution for a more efficient administration?" the Nobel Prize winner for Economics answered: "When people come from a highly centralized system, top-down decentralization is rarely successful. Citizens come to wonder why after all this time when the national government had time to create infrastructure, to efficiently use the money collected, are now asked to govern and manage themselves." What Elinor Ostrom seems to suggest, by her remark, is that such an administrative organization, although desirable, cannot be achieved easily. Nothing really true than this we think! Politicians may try to decentralize in vain if a local community is unable to assume new responsibilities. A transfer of powers that does not take into account the potential of community cannot succeed. If we were to justify the decentralized model of organization, we would allow quoting Frège Xavier, who in his "La Décentralisation" says that "the goal of decentralization is to show that the centralized system had also shortcomings". In this respect, the French author states that "centralization impoverishes social dialogue; imposing economic and social partners to organize and be represented as a priority at national level, it underestimates the essential problems of everyday life". It is well known that the centralized system has systematically neglected any form of cooperation. An "impoverished" social dialogue or even its absence does not allow moving from a culture of... conflict to one based on partnership ... and does not allow taking into consideration of common interests of social partners, reas on for which the French author sees in local social dialogue the best means of manifestation of decentralization. Trying to capture the ess ence of decentralization in his work "Decentralization and local autonomy for participatory democracy", presented at the 6th Global Forum on Reinventing Government Towards Participatory and Transparent Governance, Profess or James Katorobo thinks that "decentralization involves the transfer of political, administrative and fiscal authority fromthe central government to the authorities and the subnational governments". It is therefore in the nature of any decentralized system to experience a transfer of power from a high level of government to a lower one. Given that "many pleas for decentralization are now organized around the metaphor of local development" [4, p.70], it is fair to mention here this idea of "local development" too, which in Professor Xavier Frege's terms, is "the aim of economic and cultural of decentralization". As the French author says, "being economic, social and cultural at the same time, local development diversifies and enriches activities on a given territory by mobilizing existing resources and energies in the region" [4, p. 57]. In summary, those who must deal with affairs concerning them and manage their resources, values and mechanisms are local communities through the local authorities they have designated to represent their interests. The need for decentralization is fully justified by this argument.

\section{The Decentralization Process - Possible Solution in Overcoming the Crisis}

We dared above to put together the most important ideas expressed by specialists in the field in order to proceed now to an analysis that such a topic requires. We have to mention one thing to clear the reason why we have chosen this topic. We find that the wording "From centralization to cris is decentralization..." speaks for itself, especially since currently we star in such a phenomenon called crisis decentralization. The explanation is simple. No government would have started such a wide decentralization if the economic crisis had not happened. Moreover, we think that decentralization in crisis... is, and if we may so express ourselves, ineptitude. Why? Because the purpose of this process must be to better the "eternally-under-reform" administrative system which, in our opinion, cannot be done in cris is conditions.

\subsection{Electoral Reform on Local Government}


The UNMIK Regulation No. 2000/45 on the Self-Governance in Kosovo was the first regulatory act with legal supremacy that established the foundations of a system of democratic local self-governance in service to the citizens in the state of Kosovo. According to this Regulation, the basic unit of local self-governance in Kosovo is the municipality. The main bodies of the municipalities established by this Regulation were the following:

- The Municipal Assembly;

- The Chairpers on of the Municipal Assembly and

- $\quad$ Executive Chief

According to the UNMIK Regulation 2007/30, the main municipal bodies were:

- The Municipal Assembly

- The Mayor

The highest representative body of the municipality was the municipal as sembly through the direct vote. The power After declaration of independence, pursuant to the Law on Local Self-Government No 03/L040, adopted in February 2008 and which entered into force in June 2008, the municipal bodies are:

- $\quad$ the Municipal Assembly; and

- the Mayor.

The Assembly of the Municipality is the highest body in the municipality and it is elected directly by citizens in accordance with the Law on Local Elections. The term of the members of municipal assemblies shall be four years. The Municipal Assemblies shall establish two compulsory committees, such as:

- Committee on Policy and Finance, and

- Committee on Communities

The mayor shall be elected directly by the citizens in accordance with the law on local elections, for a term of four years. In each municipality, the mayor serves with another deputy mayor. She/he is appointed by the mayor for the same term duration and may be also dismissed by the mayor. However, the municipalities in which at least $10 \%$ of the citizens belong to the non-majority communities, there will be one deputy mayor for communities.

\subsection{Implementation of the Decentralisation Process}

The process of decentralisation and the establishment of new municipalities was preceded by the Framework

Document on Local Government Reform. The Framework Policy on Local Government Reform of 2004, devised by the Working Group on Local Governance, co-chaired by UNMIK and the Provisional Self-Governance Institution was endorsed by the Assembly of Kosovo and its purpose was to achieve the broad reform of the local governance, in order to advance and improve the local governance in Kosovo and as a result, the first pilot- municipal units were created. The implementation of the process of the decentralisation, however, continued also after the declaration of the Independence of Kosovo.

The process of local governance reform and the decentralisation was a very complex process and as such it required the adoption of numerous new laws, establishment of new municipalities and the revision of the existing ones, the reform of the local finance systemand local capacity building for an effective self-governance. Therefore the basic legislation was adopted on local self-governance in the Republic of Kosovo as provided under the Comprehensive Status Proposal for Kosovo. 


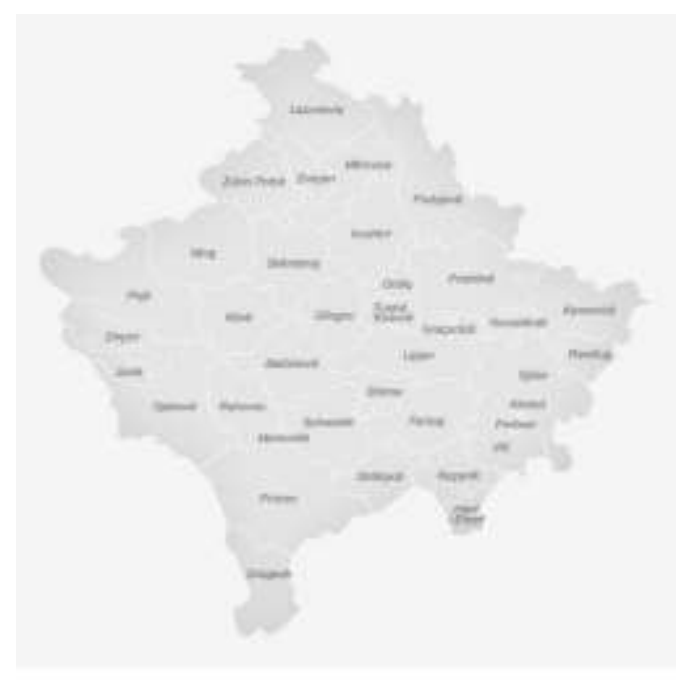

Fig.1. Map with the municipalities in the Republic of Kosovo

Based on this Accord, Kosovo passed the Law on Local Self-Governance, Law on Administrative Municipal Boundaries and the Law on Local Government Finance. Meanwhile the Inter-ministerial Group on Decentralisation is established as responsible body for coordinating the policies and actions for the establishment of the new municipalities and the implementation of the decentralization in the Republic of Kosovo, with the tasks and responsibilities defined under the Government's Decision No. 04/14 dated 3 April 2008By the chairperson's request, the IGD could invite in its meetings additional representatives of central institutions, elected representatives of municipalities and other persons that could provide advice or that could be relevant to the matters tackled, as well as international representatives from the technical assistance projects in the capacity of observers.

\subsection{Harmonization of the sectorial legislation with the legislation on Local self-governance}

To avoid the collision between laws in the future, the MLGA issues a declaration within 15 days, whereby it states whether the adopted law is in accordance with legislation on self-governance. The Ministry of Local Government Administration continued to participate in the working groups for the harmonisation of the legislation in question, constantly after the approval of the legislative strategy annually by the Government of Kosovo. The Ministry of Local Government Administration in cooperation with the Legal Office of the Prime Minister's Office identified the laws that touch upon the local self-governance, which were then harmonised with this legislation(see annexes with the list of Laws and draft laws that were drafted or amended).

\subsection{Fiscal Decentralization}

The fiscal policy in Kosovo after the war (1999) was based on revenues and expenditures of the government for the achievement of specific economic and social goals in local and central level. This was achieved initially by creating a basic fiscal policy and of a sustainable administrative system led by the Central Fiscal Authority (CFA) established in September 1999 as the builder of the fiscal policy in Kosovo. The fiscal decentralisation, allocation and transfer of competences in the fiscal sphere from central institutions into the local ones are all new phenomena in the Republic of Kosovo which only occurred following 1999. The local government revenues initially comprised only $0.35 \%$ of the overall state revenues, which were collected mainly by the central authorities and they were distributed to the local authorities in forms of unconditional grants. In order for the fiscal decentralisation to be efficient, models were sought that would enable the following:

- Bigger efficiency and responsibility for the fullest, most qualitative completion of the needs of

- citizens based on principle of subsidiarity, empowerment of the local government in collection of revenues; 
- Facilitating the coordination and harmonisation of the fiscal policy between central and local units;

- Creating conditions for competitiveness and for innovation in provision of goods and services;

- Bigger budgetary transparency etc.

The municipality can collect revenues in accordance with the laws and instructions of the Central Government on the respective regulation of these issues:

- From license fees and payments defined by the municipality;

- From the municipal revenues or assets, and

- From fines or fines percentage.

The municipal assembly collects the property tax from the following categories:

- Dwelling property;

- Commercial property;

- Industrial property;

- Agricultural property;

- Abandoned immovable property, and

- Unwilled facilities.

\section{New Public Management approach}

Recent public management reforms around the world have been affected by the New Public Management movement. Kosovo's independence and its development of the basic principles of public administration coincided with the era of the NPM ideology. That is why this approach has left a certain footprint on Kosovo's public sector. Even if major NPM reforms are analyzed rather critically or even faded away in most of the developed countries so that "[m]ost of us could write the New Public Management's post mortem now" (Lynn, 1998: 231), these principles have changed our way of thinking about public administration and we cannot go back to the unchanged situation where we started from (Peters, 2001: 199-201). Thus, NPM approach helps to understand the development and the path of changes in Kosovo municipalities. It provides a good framework for thorough analyses of the reasons and motives of the reform ideas. Widely known is the framework of Peters (2001) who grouped the features of transformation in government organizations as follows: marketization, participation, flexibility and deregulation.

While this approach gives a good overview of the major trends and prevailing thinking in public administration, the current paper also draws on it while analyzing the changes and reform ideas in Kosovo local government.

\subsection{Marketization}

The market approach for reforming government emphasizes market incentives, private sector techniques and decentralization. "The primary intellectual root of the market approach to changing the public sector is the belief in the efficiency of markets as the mechanism for allocating resources within a society" (Peters, 2001: 25). The idea behind it is the assumption that traditional bureaucracies do not provide sufficient incentives for public servants to perform efficiently and effectively. That is why the central value is the basic belief in virtue of competition. The advocates of this approach believe that the closer public sector comes to market interventions, the better the outcomes will be. Entrepreneurship, customer satisfaction, efficiency are just some central keywords used within this framework. According to this approach, good managers can produce better government with less money. For that, the managers need to have enough freedom and flexibility to be able to manage. It is believed that techniques and motivational systems from the private sector are the best ways to reach these aims. Certain political, 
legal, administrative and economic aspects hinder the marketization processes in Kosovo making it rather questionable for Kosovo local governments as well. One of the central arguments is that there is not actually any real market on Kosovo's local level.

\subsection{Participation}

Enhancing public participation involves a set of ideas and steps to facilitate citizens' participation in public administration. This approach to reforming the public sector is based on the assumption that "...governing should be

about finding out what the public wants and finding ways of delivering those services" (Peters, 2001: 50). It tries to increase the input of citizens, customers and lower-level officials in the decisionmaking processes through empowerment and facilitation. The advocates of these ideas believe that the customers themselves and the street- level officials have the most appropriate information and insights about the services and programs. If this

information was utilized appropriately, the government would perform better. Thus, in order to increase the public

administration effectiveness, public organizations should foster individual and collective participation. In addition, the theme considers involvement and participation as some of the most effective means for motivating public employees.

On the local level, the leading role of the municipalities to foster transition through participation is usually smaller than the leading role of the central government on the national level. Several authors have argued that the quality of public service delivery depends more on cooperation than on government employees simply delivering the services (Walsh, 1991; Peters, 2001). Cooperation among public organizations (meaning also among local governments) has been one of the most serious problems in Kosovo since the beginning of the transition. Since there are no common public service values or central principles in place yet, the general framework or basis for cooperation is often missing. Although partnerships between local governments, local non-governmental and business sector organizations have been promoted both by the state and local governments themselves with the common aim of finding solutions to local problems mostly in the fields like economic development, employment, social involvement, etc collaboration and networking among Kosovo local governments is still rather weak.

\subsection{Flexibility}

The third alternative approach to the traditional model of governing by Peters (2001) is characterized by flexible administration as the response to the critics of traditional rigid public administration. "Flexibility refers to the

capacity of government and its agencies to make appropriate policy responses to environmental changes" (Peters,

2001: 77). While traditional public sector organizations are often considered to be permanent entities, and public employment in many countries is regarded as a life time job, there is a modern trend to decrease this stability and to question the permanence of public organizations, structures, principles, and values. The general belief behind it is the idea of increasing societal abilities to respond fast and effectively to new challenges and to improve organizational capacities to survive in a constantly changing environment. Even if the transitional public administration systems may not be optimal at the beginning of the transition, they still offer the heavily needed framework and stability for development. Constant changes together with a high level of flexibility will blur "the picture" and may create possibilities to follow self-interests, and to build up mini-states and power spheres within public administration. In this environment, most of the energy and resources would be used for creating, managing and understanding changes while trying to find one's own place and purpose. Before a certain change has reached its maturity and outcomes, new changes are frequently already on their way 
waiting for their turn in Kosovo municipalities. Finally, there is no clear understanding about reality and "real" problems. Another serious problem in Kosovo public administration is coordination. In a time of rapid changes, together with the embracement of flexibility, actors have to become more and more involved with the various reasons and dimensions of the problems. In this context, coordination is conceptually more difficult. Changing aims and principles can easily create misunderstandings, misconceptions, as well as turf fights. The low level of coordination could easily become a central reason for the low level of efficiency. During times of rapid social, political and economic changes, stability can serve as necessary strength rather than hindering needed changes.

\subsection{Deregulation}

The fourth modern theme for reforming public administration is deregulating government while referring to internal

management of the public sector. "The fundamental assumption of the move towards deregulating government has been that if some constraints on bureaucratic action are eliminated, government could perform its functions more efficiently" (Peters, 2001: 97). Deregulating can unleash the potential of civil servants and produce higher levels of government activities. It could be considered as a subapproach of marketization through removing internal barriers and letting managers manage, or as a complimentary approach to marketization since achieving the promised efficiency through market mechanism would be much easier without rigid constraints of the public sector apparatus. Advocates of deregulation believe that using public officials' personal judgment and exercising individual discretion is superior to any sort of rules, regulations and principles, leading to better, more efficient and effective outcomes. Sometimes, some contextual factors justified the rules initially, but after some time, they might have outlived their purpose and usefulness. It might happen that the roots for deregulation are more hidden in the perception of the overregulated and dysfunctional public administration held by the public rather than in regulations themselves, hindering the actions of civil servants.

\section{Diverse Motives for NPM-Style Reform}

Thus far we have assumed that corporatization, wherever it happens, is evidence of NPM-style reform. This is not necessarily the case. We need to distinguish between two varieties of corporatization, and this brings us to the second of our five questions - the diversity of motives behind ostensibly new public management initiatives. Corporatization can take place as a means to achieve greater efficiency, cost savings or service quality improvements, in which case it is accompanied by the setting of performance targets along the lines of executive agencies. But it can also take place simply for convenience, a way of freeing a particular public function from the constraints of civil service red tape. The first is a clear example of the new public management in action; the second, much less so. There is no data to indicate with any certainty which of these two varieties of corporatization is predominant. There is no doubt, however, that the second variety is very important in its own right in many developing countries. All kinds of bodies are being converted from civil service departments to authorities, institutes, corporations, companies and other kinds of free-standing public bodies, even in countries which have no systematic programme of corporatization along Kosovo lines. There are two reasons behind this trend. First, most developing countries have been corporatizing government functions for decades: there is little new about this, save that the trend may have accelerated in recent years. And secondly, the management constraints which newly corporatized bodies are being set up to escape can be very severe. In many developing or less developed countries, such constraints go beyond the procedural red tape which those familiar with government in industrialized countries would expect to find. They can extend to, among other things, public-private pay gaps that are so wide after years of restraint coupled with galloping inflation that it becomes impossible to recruit and retain qualified staff (Cohen 1995; Colclough 1997a; Klitgaard 1997b).

\section{Is The New Public Management Appropriate For Developing Countries?}


Having reviewed the evidence concerning the take-up of the new public management in developing countries, we can now turn our attention to the question of its appropriateness. At first sight the failure rate of NPM reforms might seem enough to lead us to a negative conclusion. But it would be a mis take to look at the new public management in is olation. Our brief survey of non-NPM reforms shows that these have done no better. Adminis trative reform has always had a high failure rate, in both developed and developing countries (Caiden 1991; Kiggundu 1998). So if one is to argue that NPM reforms are inappropriate for developing countries on the bas is of their poor record of implementation, one may as well say the same for any kind of administrative reform. The real test of the appropriateness of NPM is not at the output stage of reform (implementation, where most reforms currently fail), but at that of outcomes (end results of successfully implemented changes). In other words, even if some means were

found to overcome the implementation hurdle, even if it were possible to ensure that changes are not blocked or kept cosmetic, would NPM-style initiatives yield their expected benefits in a developingcountry environment? Or would they not, perhaps even generating perverse outcomes? Broadly speaking, we can identify three interrelated arguments along such lines. Let us look at them in sequence. The first argument may be labeled the 'stages of development' thesis, variant one. The lack of expertise and the unreliability of information systems in developing countries, so this argument goes, means that it is not viable to develop complex structures such as internal markets or sophisticated performance monitoring systems. Such mechanisms would be unreliable at best, unworkable at worst. On the contrary, developing countries should concentrate on establishing more effective mechanisms of central controlover functions such as staffing or finance, because this is the precursor of any eventual delegation (Holmes 1992; Nunberg 1995). This argument draws on the historical record of developed countries.

\section{Public Entrepreneurship as a Local Governance Strategy in Decentralizing Polity}

\subsection{Management Stream}

The global movement for entrepreneurial governments, which the United Kingdom and the United States Government has initiated in the 1980's and 1990's respectively, has led to the use of a whole battery of new and differing alternative solutions to problems besetting government underperformance. In the Philippines, the manifestations of the management stream as a pre-condition for public entrepreneurship structure are mandated under the Philippine Local Government Code. This emanates from Section 18:"Local Government Units shall have the power and authority to establish an organization that shall be responsible for the efficient and effective implementation of their development plans, programs, objectives and priorities; to levy taxes, fees and charges which shall accrue exclusively for their use and disposition and shall be retained by them ... to apply their resources and assets for productive, developmental or welfare purpose, in the exercise or furtherance of their government or propriety powers and functions and thereby ensure their development into self-reliant communities and active participants in the attainment of national goals." The general welfare clause of Section 16 is also seen as a condition in the emergence of public entrepreneurship under decentralization: "Every local government unit shall exercise the powers expressly granted, those necessary implied therefrom, as well as powers necessary, appropriate, or incidental for its efficient and effective governance and those which are essential for the promotion of the general welfare." These increased managerial powers given by the code have also been vehicles for creativity and innovations in local government units and acceleration of local development. Through the code, creative local officials have made many reforms in recent years and a new breed of local executives and officials has even been spawned, which a decade ago was unthinkable. In this new system, McCourt and Minogue(2001:5)identified that there is no clear separation of politics and management especially on the roles of administrators and politicians, which are often fused together. 


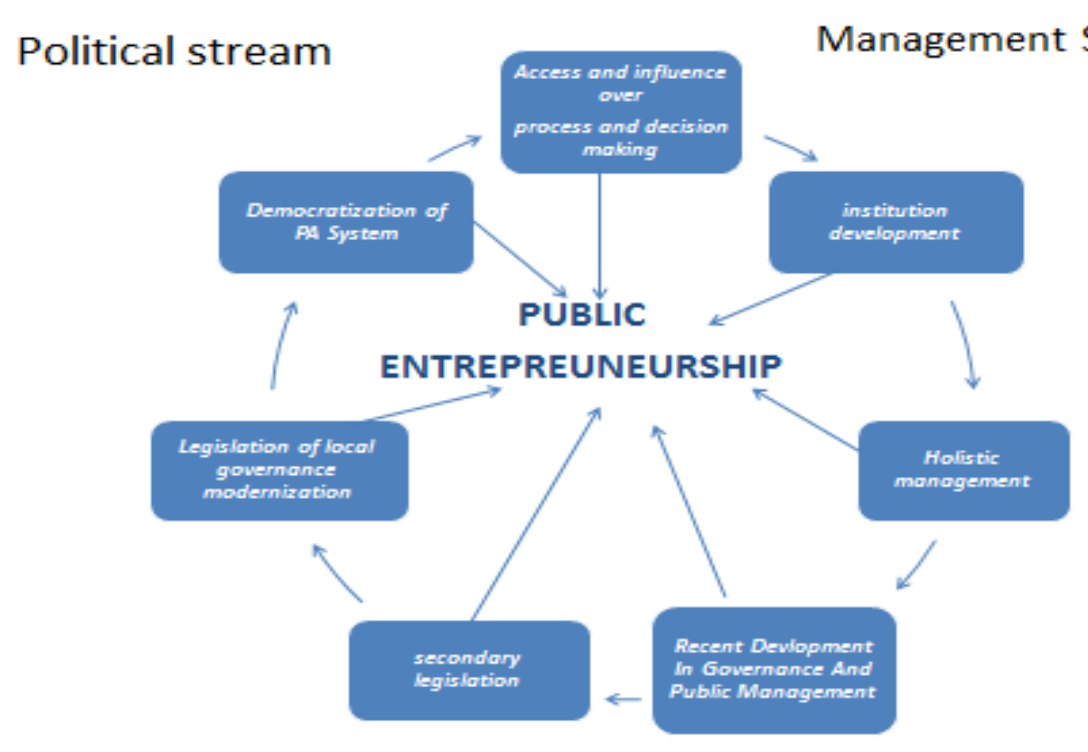

Fig. 2. Some Conditions for the Emergence of Public Entrepreneurship

\section{Conclusions}

While the reforms in Kosovo municipalities have brought about some positive change, the transformation of Kosovo local governments has not been easy. First, there are serious questions raised concerning the appropriateness of modern management approaches in the public sector at all. Second, transitional countries share problems rather than solutions with Western countries. In transitional countries, the legitimacy of the public sector has been suffering due to the negative nature of the communist pre-transition regime. The instability of the systems, the constantly changing targets and the low level of administrative capacity create extra problems for the public organizations. Because of transition, there has been significant pressure to adopt popular policies and approaches in Kosovo local governments without having enough time to analyze and adopt these ideas in depth. Third, the limited human resources, the special characteristics of the organizational culture and the prevailing common values in Kosovo municipalities make the situation even fuzzier. Managers with too little experience in the public sector or in change management may often fall into the trap of "fashionable approaches" while overestimating the positive outcomes of the new ideas and underestimating the negative drawbacks. Especially dangerous can be ready-made-for-use models and ideas that, due to lack of knowledge and broader understanding, might look promising. The research comes to the conclusion that all of the four discussed NPM themes - marketization, participation, flexibility and deregulation might offer remedies to public organizations in the Western world (though even that is often questionable), but they should be implemented very consciously in Kosovo local governments. Critical thinking and a broader analysis of Kosovo local governments is needed before any of these principles would be implemented. Municipalities, together with citizens, the private and the non-profit sector, can all make an important contribution while supporting and facilitating the general transition, but only a strong public sector as a greater whole can handle the effective execution of policies and sustainable transition. While the situation on the Kosovo local level is similar to the situation in other CEEcountries in many respects, the same conclusion will most probably apply to other transitional countries and their local administration as well. Admitting all this and in light of the already mentioned ideas we now consider ourselves entitled to give a number of personal opinions. We cannot deny the fact that decentralization is at the center of political debate and economic crisis. Concerned about finding a 
legitimation to the decentralized model, we see as justified the following question: What is the point of decentralization? The answer is simple. A generous one, we think. Why? Because it increas es economic efficiency and the transparency of the democratic process. And how does it do that? In that it facilitates the connection between the resource provider - the taxpayer - and the service provider - the public institution. On one hand, decentralization of public institutions makes them more responsible in front of the local communities, reducing the "democratic deficit" and bringing near the customer - the taxpayer - to the public service provider. On the other hand, service providers find it easier to discover the real needs of community members by getting faster feedback from them. We have also thought of another explanation. Could it be that decentralization places on the shoulders of local authorities the responsibility for the crisis? Such a question is more legitimate in the context of the current "efforts" for decentralization. The answer cannot be otherwise. Although local authorities can be put in an awkward situation and not fully meet the expectations of communities things can be seen differently and solutions can be found more easily from a closer position... even in times of crisis.

\section{References:}

1. Aucoin, P. (1990) Administrative Reform in Public Management: Paradigms, Principles, Paradoxes and Pendulums,

2. Governance, $3 / 2$, pp. 115-37.

3. Barzelay, M. (2001) The New Public Management, California: University of California Press.

4. Bozeman, B. (2002) Public-Value Failure: When Efficient Markets May, Not Do, Public Administration Review,

5. 62/2, pp. 145-61.

6. Drechsler, W. (2005) The Re-Emergence of "Weberian" Public Administration after the Fall of New Public

7. Management: The Central and Eastern European Perspective, Halduskultuur, 6, pp. 94-108.

8. Fenwick, J., Elcock, H. (2004) The New Political Management in Local Government: Public Engagement or Public

9. Indifference?, Local Government Studies, 30/4, pp. 519-37.

10. Forde, C. (2005) Participatory Democracy or Pseudo-Participation? Local Government Reform in Ireland, Local

11. Government Studies, 31/2, pp. 137-48.

12. Gray, B. (1985) Conditions Facilitating Inter organizational Coordination, Human Relations, 38, pp. 911-36. Holmes, L. (1997) Post-Communism: An Introduction, Cambridge and Oxford, Polity Press.

13. Hood, C. (1991) A Public Management for All Seasons?, Public Administration, 69/1, pp. 3-19.

14. Jubb, P., Kelso, R. (1998) Ethics, Pluralism and Public Service, Accounting Forum, 21/3-4, pp. 43360.

15. Parker, L., Gould, G. (1999) Changing Public Sector Accountability: Critiquing New Directions, Accounting

16. Forum, 23/2, pp. 109-35.

17. Peters, B. G. (2001) The Future of Governing (2nd edn), Kansas: University Press of Kansas.

18. Pollitt, C., Bouckaert, G. (2004) Public Management Reform (2 edn), Oxford: Oxford University Press. Pratchett, L. (1999) Introduction: Defining Democratic Renewal, Local Government Studies, 25/4, pp. 1-18. Raagmaa, G. (1996) Shifts in regional development of Kosovo during the transition, European Planning Studies,

19. 4/6, pp. 683-703.

20. Randma-Liiv, T. (2005a) Performance Management in Transitional Administration: Introduction of Pay-for- Performance in the Kosovo Civil Service, Journal of Comparative Policy Analysis, 7/1, pp. 95-119.

21. Doig, Alan (1997). 'The Privatisation of the Property Services Agency: Risk and Vulnerability in Contract-Related

22. Fraud and Corruption'. Public Policy and Administration 12(3): 6-27. 
23. Goldsmith, Arthur A. (1999). 'Africa’s Overgrown State Reconsidered: Bureaucracy and Economic Growth'. World

24. Politics 51(4): 520-46.

25. Greenaway, John (1995). 'Having the Bun and the Halfpenny: Can Old Public Service Ethics Survive in the New

26. Whitehall?'. Public Administration 73(3): 357-74.

27. Grindle, Merilee S. (1997). 'Divergent Cultures? When Public Organizations Perform Well in Developing

28. Countries'. World Development 25(4): 481-95.

29. Harrigan, Jane (1998). 'Effects of the IMF and World Bank on Public Expenditure Accountability in Jamaica'.

30. Public Administration and Development 18(1): 5-22.

31. Holmes, Malcolm (1992). 'Public Sector Management Reform: Convergence Or Divergence?'. Governance 5(4):

32. 472-83.

33. Hood, Christopher (1991). 'A Public Management For All Seasons?'. Public Administration 69(1): $3-19$. 